\title{
PENGARUH TERAPI YOGA TERHADAP PENURUNAN TEKANAN DARAH PADA PENDERITA HIPERTENSI
}

\author{
Rr. Sri Endang Pujiastuti ${ }^{1}$, Sawab $^{2}$, Safitri Zummy Afiyati ${ }^{3}$ \\ ${ }^{1}$ Poltekkes Kemenkes Semarang Departement Keperawatan \\ rarastuti@yahoo.com
}

\begin{abstract}
Abstrak
Hipertensi disebut silent disease karena biasanya pasien tidak sadar bahwa dirinya mengalami hipertensi. Hipertensi dapat menyerang siapa saja dari berbagai kelompok umur maupun kelompok sosial ekonomi. Pengobatan Hipertensi tidak harus menggunakan tidakan farmakologis, namun hipertensi dapat diobat menggunakan terapi non farmakologis berupa terapi yang berbentuk meditasi berupa terapi yoga. Penelitin ini bertujuan untuk mengetahui pengaruh pemberian terapi yoga terhadap penurunan kecemasan dan tekanan darah pada penderita Hipertensi. Metode ini adalah desain Quasieksperimental dilakukan di Kelurahan Pedalangan RW 01. Sampel adalah 60 penderita hipertensi primer, yang secara acak dikelompokkan menjadi dua kelompok yaitu kelompok intervensi $(n=30)$ dan kelompok kontrol $(\mathrm{n}=30)$. Hasil Analisa penelitian ini menunjukkan pada tekanan darah sistole dengan nilai $p$ value $0,001(\mathrm{p}<0.05)$ dan tekanan darah diastole dengan nilai $p$ value $0,000(\mathrm{p}<0.05)$ pada kelompok intervensi dan kontrol setelah dilakukan yoga. Ada pengaruh yoga terhadap penurunanmtekanan darah pada penderita hipertensi. Peneliti menyarankan kepada semua tenaga kesehatan untuk menerapkan terapi yoga kepada pasien hipertensi karena yoga mampu menurunkan tekanan darah.
\end{abstract}

Kata kunci: Yoga, tekanan darah, hipertensi

\begin{abstract}
The effect of yoga therapy to decrease blood pressure in patients with hypertension. Hypertension is called the silent disease, it's usually caused an patient not be aware that they was being hypertension. Hypertension can affect anyone of various age groups and socio-economic groups. Hypertension can treatment should not used pharmacological, measure, however hypertension can treatment by nonpharmacologycal teraphy a form of transcedental meditation or yoga. The purpose of this research is conducted to determine the effect of yoga therapy to decrease blood pressure in patients with hypertension. This method design Quasi-experimental done in Pedalangan village RW 01. The sample was 60 subject primary hypertension, who were randomized include 2 groups: there was intervention group $(n=30)$ and control group $(n=30)$. Analysis result Man Whitney experiment systolic blood pressure $p$ value $0.001(P<0.05)$ and diastolic blood pressure with $p$ value $0.000(p<0.05)$ in the intervention and control groups after yoga. There is the influence of yoga to lowering blood pressure in hypertensive patients. Researchers suggest to all health workers to apply yoga therapy to patients with hypertension because yoga can lower blood pressure.
\end{abstract}

Keywords: Yoga, blood pressure, hypertension

\section{Pendahuluan}

Penuaan atau proses menjadi tua adalah suatu kondisi yang normal, yang akan ditandai dengan perubahan fisik dan tingkah laku yang dapat diprediksi dan terjadi pada semua orang saat mereka mencapai usia tahap perkembangan kronologis tertentu (Stanley \& Beare, 2007). Dengan bertambahnya usia, akan besar kemungkinan seseorang mengalami permasalah fisik, jiwa, spiritual, ekonomi dan sosial. Masalah yang sangat mendasar pada lanjut usia adalah masalah kesehatan yang merupakan akibat proses degeneratif.
Pada proses degenerasi pada lansia, salah satunya menyebabkan waktu tidur yang efektif semakin berkurang, dan menyebabkan tidak tercapainya kualitas tidur yang adekuat dan menyebabkan berbagi macam keluhan tidur (Chasanah,2017).

Proses degenerasi pada lansia menyebabkan waktu tidur yang efektif semakin berkurang, dan menyebabkan tidak tercapainya kualitas tidur yang adekuat dan menyebabkan berbagi macam keluhan tidur. Prevalensi pemenuhan gangguan pemenuhan kebutuhan tidur 
pada lansia cukup meningkat yaitu sekitar $76 \%$. Kelompok lansia lebih mengeluh mengalami sulit tidur sebanyak $40 \%$, sering terbangun pada malam hari sebanyak $30 \%$ dan sisanya gangguan pemenuhan kebutuhan tidur lain (Amir, 2007). Hasil penelitian Khasanah (2012) menunjukkan bahwa 29 reponden $(29,9 \%)$ memiliki kualitas tidur baik dan 68 responden $(70,1 \%)$ memiliki kualitas tidur buruk atau jelek. Hasil penelitian ini didapatkan data bahwa tidur Lansia di Balai Rehabilitasi Sosial " Mandiri " Semarang, dapat disimpulkan bahwa secara keseluruhan kualitas tidur lansia buruk. Hasil ini dapat digunakan sebagai gambaran bagi perawat untuk bisa memanfaatkan data dalam penelitian ini sehingga mampu melakukan asuhan keperawatan pada lansia terkait kebutuhan istirahat tidur.

Perubahan pola tidur lansia disebabkan perubahan sistem neurologis yang secara fisiologis akan mengalami penurunan jumlah dan ukuran neuron pada sistem saraf pusat. Hal ini mengakibatkan fungsi dari neurotransmiter pada sistem neurologi menurun, sehingga distribusi norepinefrin yang merupakan zat untuk merangsang tidur juga akan menurun. Lansia yang mengalami perubahan fisiologis pada sistem neurologis menyebabkan gangguan tidur (Potter\&Perry,2005; Stanley, 2007).

$$
\text { Perubahan tidur yang }
$$

mempengaruhi kualitas tidur yang berhubungan dengan proses penuaan pada seperti meningkatkan latensi tidur, efisiensi tidur berkurang, bangun lebih awal, mengurangi tahapan tidur nyenyak dan gangguan irama sirkardian, peningkatan tidur siang. Jumlah waktu yang dihabiskan untuk tidur lebih dalam menurun. Lansia melaporkan sering tidur siang dan mengalami kesulitan jatuh tertidur dan tetap tidur (Stanley, 2006; Oliveira, 2010).

Gangguan tidur secara umum merupakan keadaan dimana terjadi perubahan kuantitas dan kualitas tidur yang dapat menimbulkan rasa tidak nyaman dan berdampak pada kualitas dan gaya hidup. Insomnia merupakan salah satu gangguan tidur yang banyak dikeluhkan masyarakat. Insomnia pada lansia disebabkan oleh beberapa faktor, diantaranya adalah faktor status kesehatan, penggunaan obat-obatan, kondisi lingkungan, stress psikologis, asupan nutrisi/diet dan pola hidup (Darmojo dan Martono, 2006). Kualitas tidur merupakan suatu penyusun penting dan bagian yang esensial dari kualitas hidup seseorang (Luo dkk, 2013).

Terdapat beberapa faktor yang mempengaruhi kualitas tidur seseorang, diantaranya adalah : 1)Fisik Kondisi, fisik seseorang sangat erat kaitannya dengan kualitas tidur yang dimilikinya. Terutama pada lansia dengan keluhan ketidaknyamanan fisik seperti batuk, kram kaki, pegal-pegal pada tubuh dan perut kembung cenderung mengalami penurunan kualitas tidur . 2)Psikososial Memasuki fase lansia akan membuat seseorang mengalami perubahan dalam hal psikososial. Lansia mudah mengalami kecemasan dan kekhawatiran berlebih serta depresi yang dapat mengganggu tidur mereka, 3)Lingkungan Faktor lingkungan ikut berkontribusi dalam mempengaruhi kualitas tidur seseorang. 4)Gaya Hidup, Gaya hidup tentu memberikan pengaruh yang besar terhadap kualitas tidur seseorang. Terutama pada lansia, tidur siang yang pendek dan diikuti dengan latihan fisik sedang pada sore hari dapat memberikan kualitas tidur yang baik (Wahyuni dkk, 2009). Menghentikan aktivitas fisik seperti hubungan sosial dengan teman, pekerjaan dan berada di dalam kamar sepanjang hari terbukti meningkatkan kemungkinan terjadi insomnia (Leblanc dkk, 2015). Kebiasaan mengkonsumsi alkohol dan merokok, serta minum kopi sebelum tidur dapat mengganggu pola tidur normal (Wahyuni dkk, 2009).

Lansia umumnya ditemukan perubahan berupa kedalaman tidur yang terganggu, sehingga apabila terdapat stimulus dari lingkungan disekitarnya, 
maka lansia akan lebih sering terbangun dibandingkan dengan orang dewasa muda normal yang terbangun hanya 2-4 kali dalam semalam (Darmojo dan Martono, 2006). Adanya penurunan jumlah total waktu tidur, mudah terbangun di malam hari dan terbangun lebih awal dapat memberikan perasaan tidak segar di pagi hari dan kepuasan tidur yang berkurang (Wahyuni dkk, 2009). Hal tersebut berdampak pada munculnya keluhan mengantuk, keletihan dan mudah jatuh tidur di siang hari. Lansia cenderung pergi ke tempat tidur lebih awal dibandingkan dengan orang dewasa muda (Voinescu dan Tatar, 2015) namun membutuhkan waktu yang lama untuk jatuh tertidur (latensi tidur memanjang) dan lebih sering terbangun di malam hari (Wahyuni dkk, 2008).

Hasil survei awal dengan wawancara terhadap 20 lansia di posbindu "Kemuning" kelurahan candirejo didapatkan data bahwa $70 \%$ diantaranya mengeluh susah tidur di malam hari, pergi tidur antara jam 7 sampai jam 9, tapi ada juga yang tidur jam 10. Lansia mengatakan sering terbangun pada malam hari rata-rata 2-3 kali untuk ke kamar mandi dan setelah itu sulit untuk jatuh tertidur lagi. Kondisi lain yang di alami lansia sehingga terbangun pada malam hari dikarenakan merasakan nyeri, terbangun karena mimpi dan keadaan lingkungan yang berisik. Keluhan lain yang dialami lansia adalah merasa kurang segar setelah bangun di pagi hari, mengantuk di siang hari namun ada 5 lansia yang mengeluh tidak bisa tidur disiang hari walaupun sudah mengantuk serta ada keinginan untuk tidur. Maka diperlukan intervensi untuk meningkatkan kualitas tidur pada lanjut usia yang mengalami insomnia. Salah satu intervensi mandiri yang dapat diberikan adalah terapi Beapreasi.

Tujuan Penelitian ini adalah untuk mengetahui pengaruh Terapi Beapreasi terhadap kualitas tidur pada lansia dengan insomnia di Posbindu kemuning kelurahan candirejo. Adapun luaran yang akan dihasilkan pada penelitian ini adalah adanya alternative intervensi dalam kualitas tidur pada lansia yang mengalami insomnia serta meningkatkan ketrampilan perawat dalam perawatan di komunitas untuk lanjut usia. Intervensi ini bisa diterapkan dalam pemberian asuhan keperawatan pada lansia untuk meningkatkan kualitas tidur lansia dengan insomnia. Hipertensi disebut silent disease karena biasanya pasien tidak mengetahui adanya tanda-tanda Hipertensi. Hipertensi dapat menyerang siapa saja dari berbagai kelompok umur maupun kelompok sosial ekonomi (Astawan, 2007). Hipertensi menjadi masalah kesehatan yang besar di seluruh dunia saat ini karena jumlah angka prevalensi penderita Hipertensi yang tinggi dan berhubungan dengan resiko terjadi penyakit kardiovaskuler (World Health Organization, 2010).

Menurut
Organization (2014) $\quad \begin{array}{r}\text { Health } \\ \text { penyakit }\end{array}$

kardiovaskular merupakan pembunuh nomor satu dunia untuk usia diatas 45 tahun dan akan diperkirakan 12 juta orang meninggal setiap tahunnya. Hipertensi secara global menyebabkan 7,6 juta kematian atau sekitar $12,8 \%$ dari total seluruh kematian.Hipertensi menyebabkan stroke, retinopati kebutaan, penyakit jantung koroner untuk gagal jantung, gagal ginjal kronis gagal ginjal terminal (Bild et al., 2014).

Hipertensi dapat diobat dengan cara mengkonsumsi obat-obatan penurun tekanan darah, pengaturan pola makan, olahraga, mengurangi stress, menghindari alcohol, dan merokok (Kowalski, 2010). Menurut Prayitno (2014) Hipertensi juga dapat diobati menggunakan terapi yang berbentuk meditasi berupa yoga. Meditasi didalamnya mengandung unsur penerangan diri yang dapat menstabilkan tekanan darah sehingga meditasi dianggap sebagai metode penyembuhan yang sangat efektif bagi penderita Hipertensi.

Yoga merupakan terapi yang mengkombinasikan antara teknik bernapas, relaksasi dan meditasi serta latihan 
peregangan (Jain, 2011). Manfaat yoga secara umum menurut Wirawanda (2013) meningkatkan kekuatan, meningkatkan kelenturan, melatih keseimbangan, mengurangi nyeri, melatih pernapasan, melancarkan fungsi organ, ketenangan batin serta meningkatkan konsentrasi dan kecerdasan.

Ada beberapa penelitian yang sudah dilakukan oleh peneliti untuk menjelaskan tentang yoga untuk menurunkan tekanan darah. Salah satunya penelitian yang dilakukan oleh Devi oktavia tentang Pengaruh latihan yoga terhadap penurunan tekanan darah pada lanjut usia (lansia) dengan hasil penurunan tekanan darah sistolik sebesar $32,4 \mathrm{mmHg}$ dan tekanna darah diatolik sebesar 13,38 $\mathrm{mmHg}$ dengan nilai $p<0,05$ yang artinya terdapat pengaruh yang signifikan antara tekanan darah sebelum dan sesudah melakukan latihan yoga.

Penelitian lain sebagaimana dilakukan oleh Andri Sasmita, dkk tentang Pengaruh Latihan Hatha Yoga Selama 12 Minggu Terhadap Tekanan Darah Diastol dan Sistol Wanita Berusia 50 Tahun Keatas dengan hasil terdapat Dari data yang terkumpul didapatkan 37 subyek penelitian, didapatkan penurunan tekanan darah diastol yang signifikan $(p<0,05)$ dan Sistol tidak signifikan $(p>0,05)$ yang artinya latihan yoga terprogram selama 12 minggu dapat menurunkan tekanan darah diastol tetapi tidak pada tekanan darah sistol wanita yang berusia 50 tahun ke atas

Berdasarkan fenomena diatas peneliti tertarik untuk melakukan penelitian mengenai pengaruh terapi yoga terhadap penurunan tekanan darah pada penderita Hipertensi secara kuantitatif dengan pemeriksaan tekanan darah pada pasien hipertensi primer.

\section{Metode}

Penelitian ini menggunakan Quasi Experiment dengan pendekatan pre-post test control group design. Penelitian ini dilakukan di Kelurahan Pedalangan RW 01 pada tanggal 6-24 Desember 2017. Populasi dalam penelitian ini adalah seluruh pasien hipertensi di kelurahan Pedalangan RW 01 sejumlah 60 orang. Sampel pada penelitian ini seluruh penderita Hipertensi yang ada di Kelurahan Pedalangan RW 01. Teknik sampling pada penelitian ini adalah Total sampling.

Kriteria inklusi adalah Penderita Hipertensi primer yang memiliki kecemasan ringan-sedang, Penderita hipertensi yang tidak sedang menjalani pengobatan di Puskesmas, Penderita hipertensi yang belum pernah mendapatkan terapi yoga. Instrumen yang digunakan pada penelitian ini adalah lembar observasi tekanan darah . Pengolahan data bivariat penelitian ini menggunakan Uji Wilcoxon dan Mann Whitney Test.

\section{Hasil}

Tabel 1.

Umur responden pada kelompok intervensi dan kelompok control $(n=30)$

\begin{tabular}{|c|c|c|c|c|c|c|}
\hline \multirow[t]{2}{*}{ Umur } & \multicolumn{3}{|c|}{ Intervensi } & \multicolumn{3}{|c|}{ Kontrol } \\
\hline & $\mathrm{f}$ & $\begin{array}{c}\text { Tekanan } \\
\text { darah sistole }\end{array}$ & $\begin{array}{c}\text { Tekanan darah } \\
\text { diastole }\end{array}$ & $\mathrm{f}$ & $\begin{array}{l}\text { Tekanan darah } \\
\text { sistole }\end{array}$ & $\begin{array}{c}\text { Tekanan darah } \\
\text { diastole }\end{array}$ \\
\hline & & $\begin{array}{l}\text { Hipertensi } \\
\text { grade } 1\end{array}$ & $\begin{array}{l}\text { Hipertensi } \\
\text { grade } 1\end{array}$ & & & \\
\hline $30-40$ & $\begin{array}{c}5 \\
(16,7 \%)\end{array}$ & $\begin{array}{c}5 \\
(16,7 \%)\end{array}$ & $\begin{array}{c}5 \\
(16,7 \%)\end{array}$ & $\begin{array}{c}1 \\
(3,3 \%)\end{array}$ & $\begin{array}{c}1 \\
(3,3 \%)\end{array}$ & $\begin{array}{c}1 \\
(3,3 \%)\end{array}$ \\
\hline $41-50$ & $\begin{array}{c}14 \\
(46,7 \%) \\
\end{array}$ & $\begin{array}{c}14 \\
(46,7 \%) \\
\end{array}$ & $\begin{array}{c}14 \\
(46,7 \%) \\
\end{array}$ & $\begin{array}{c}15 \\
(50,0 \%) \\
\end{array}$ & $\begin{array}{c}15 \\
(50,0 \%) \\
\end{array}$ & $\begin{array}{c}15 \\
(50,0 \%) \\
\end{array}$ \\
\hline $51-60$ & $\begin{array}{c}11 \\
(36,7 \%)\end{array}$ & $\begin{array}{c}11 \\
(36,7 \%)\end{array}$ & $\begin{array}{c}11 \\
(36,7 \%)\end{array}$ & $\begin{array}{c}14 \\
(46,7 \%)\end{array}$ & $\begin{array}{c}14 \\
(46,7 \%)\end{array}$ & $\begin{array}{c}14 \\
(46,7 \%)\end{array}$ \\
\hline
\end{tabular}


Tabel 1 menunjukan diskripsi frekuensi dan presentase karakteristik responden berdasarkan umur paling banyak baik pada kelompok intervensi dan kontrol yaitu responden berusia 41-50 tahun.

Tabel 2.

Pekerjaan responden pada kelompok intervensi dan kelompok kontrol

\begin{tabular}{lcccccc}
\hline Pekerjaan & \multicolumn{3}{c}{$\begin{array}{c}\text { Intervensi } \\
(\mathrm{n}=30)\end{array}$} & $\begin{array}{c}\text { Kontrol } \\
(\mathrm{n}=30)\end{array}$ & \\
& $\mathrm{f}$ & $\begin{array}{c}\text { Tekanan } \\
\text { darah } \\
\text { sistole }\end{array}$ & $\begin{array}{c}\text { Tekanan } \\
\text { darah } \\
\text { diastole }\end{array}$ & $\mathrm{F}$ & $\begin{array}{c}\text { Tekanan } \\
\text { darah } \\
\text { sistole }\end{array}$ & $\begin{array}{c}\text { Tekanan } \\
\text { darah } \\
\text { diastole }\end{array}$ \\
\hline PNS & & $\begin{array}{c}\text { Hipertensi } \\
\text { grade 1 }\end{array}$ & $\begin{array}{c}\text { Hipertensi } \\
\text { grade } 1\end{array}$ & & $\begin{array}{c}\text { Hipertensi } \\
\text { grade 1 }\end{array}$ & $\begin{array}{c}\text { Hipertensi } \\
\text { grade 1 }\end{array}$ \\
& 2 & 2 & 2 & 1 & 1 & 1 \\
Tidak bekerja & $(6,7 \%)$ & $(6,67 \%)$ & $(6,67 \%)$ & $(3,3 \%)$ & $(3,3 \%)$ & $(3,3 \%)$ \\
& $(66,7 \%)$ & $(66,7 \%)$ & $(66,7 \%)$ & $(60,0 \%)$ & $(60,0 \%)$ & $(60,0 \%)$ \\
Wiraswasta & 3 & 3 & 3 & 6 & 6 & 6 \\
& $(10,0 \%)$ & $(10,0 \%)$ & $(10,0 \%)$ & $(20,0 \%)$ & $(20,0 \%)$ & $(20,0 \%)$ \\
Karyawan & 5 & 5 & 5 & 5 & 5 & 5 \\
swasta & $(16,7 \%)$ & $(16,7 \%)$ & $(16,7 \%)$ & $(16,7 \%)$ & $(16,7 \%)$ & $(16,7 \%)$ \\
\hline
\end{tabular}

Tabel 2 menunjukan diskripsi hipertensi baik pada kelompok intervensi frekuensi dan presentase karakteristik responden berdasarkan pekerjaan yang paling banyak mengalami masalah dan kontrol yaitu responden yang tidak bekerja.

Tabel 3.

Tingkat Pendidikan responden pada kelompok intervensi dan kelompok kontrol

\begin{tabular}{|c|c|c|c|c|c|c|}
\hline \multirow[t]{3}{*}{$\begin{array}{c}\text { Tingkat } \\
\text { Pendidikan }\end{array}$} & \multicolumn{3}{|c|}{$\begin{array}{l}\text { Intervensi } \\
(\mathrm{n}=30)\end{array}$} & \multicolumn{3}{|c|}{$\begin{array}{l}\text { Kontrol } \\
(\mathrm{n}=30)\end{array}$} \\
\hline & $\mathrm{f}$ & $\begin{array}{c}\text { Tekanan } \\
\text { darah sistole }\end{array}$ & $\begin{array}{c}\text { Tekanan darah } \\
\text { diastole }\end{array}$ & $f$ & $\begin{array}{c}\text { Tekanan } \\
\text { darah sistole }\end{array}$ & $\begin{array}{c}\text { Tekanan darah } \\
\text { diastole }\end{array}$ \\
\hline & & $\begin{array}{l}\text { Hipertensi } \\
\text { grade } 1\end{array}$ & $\begin{array}{l}\text { Hipertensi } \\
\text { grade } 1\end{array}$ & & $\begin{array}{l}\text { Hipertensi } \\
\text { grade } 1\end{array}$ & $\begin{array}{l}\text { Hipertensi } \\
\text { grade } 1\end{array}$ \\
\hline SMP & $\begin{array}{c}9 \\
(30,0 \%)\end{array}$ & $\begin{array}{c}9 \\
(30,0 \%)\end{array}$ & $\begin{array}{c}9 \\
(30,0 \%)\end{array}$ & $\begin{array}{c}9 \\
(30,0 \%)\end{array}$ & $\begin{array}{c}9 \\
(30,0 \%)\end{array}$ & $\begin{array}{c}9 \\
(30,0 \%)\end{array}$ \\
\hline SMA & $\begin{array}{c}19 \\
(63,3 \%)\end{array}$ & $\begin{array}{c}19 \\
(63,3 \%)\end{array}$ & $\begin{array}{c}19 \\
(63,3 \%)\end{array}$ & $\begin{array}{c}19 \\
(63,3 \%)\end{array}$ & $\begin{array}{c}19 \\
(63,3 \%)\end{array}$ & $\begin{array}{c}19 \\
(63,3 \%)\end{array}$ \\
\hline $\begin{array}{l}\text { Perguruan } \\
\text { tinggi }\end{array}$ & $\begin{array}{c}2 \\
(6,7 \%)\end{array}$ & $\begin{array}{c}2 \\
(5,7 \%)\end{array}$ & $\begin{array}{c}2 \\
(5,7 \%)\end{array}$ & $\begin{array}{c}2 \\
(6,7 \%)\end{array}$ & $\begin{array}{c}2 \\
(6,7 \%) \\
\end{array}$ & $\begin{array}{c}2 \\
(6,7 \%)\end{array}$ \\
\hline
\end{tabular}

Tabel 3 menunjukan diskripsi

frekuensi dan presentase karakteristik responden berdasarkan tingkat pendidikan yang paling banyak mengalami masalah hipertensi baik pada kelompok intervensi dan kontrol yaitu responden yang bertingkat pendidikan SMA. 


\section{Tabel 4.}

Nilai rata-rata tekanan darah sistole dan diastole sebelum dilakukan terapi yoga pada kelompok intervensi dan kelompok kontrol

\begin{tabular}{lcccc}
\hline \multicolumn{1}{c}{ Variabel } & Mean & SD & Min & Max \\
\hline Tekanan darah sistole & & & & \\
Intervensi & 147,73 & 5,452 & 140 & 156 \\
Kontrol & 148,87 & 5,673 & 140 & 156 \\
\hline Tekanan darah diastole & & & & \\
Intervensi & 94,27 & 2,504 & 90 & 98 \\
Kontrol & 94,20 & 2,369 & 90 & 98 \\
\hline
\end{tabular}

Hasil penelitian menunjukkan ratarata tekanan darah sistole sebelum perlakuan pada kelompok intervensi adalah $147,73 \mathrm{mmHg}$ (Hipertensi grade 1) dengan standar deviasi 5,452. Tekanan sistole tertinggi $156 \mathrm{mmHg}$ dan terendah 140 mmHg. Kelompok kontrol sebesar $148,87 \mathrm{mmHg}$ (Hipertensi grade 1)dengan standar deviasi 5,673 .Tekanan darah tertinggi $156 \mathrm{mmHg}$ dan terendah 140 $\mathrm{mmHg}$.
Rata-rata tekanan darah diastole sebelum perlakuan pada kelompok intervensi adalah 94,27 $\mathrm{mmHg}$ (Hipertensi grade 1) dengan standar deviasi 2,504. Tekanan diastole tertinggi $98 \mathrm{mmHg}$ dan terendah $90 \mathrm{mmHg}$. Kelompok kontrol sebesar $94,20 \mathrm{mmHg}$ (Hipetensi grade 1) dengan standar deviasi 2,369. Tekanan darah diastole tertinggi 98 $\mathrm{mmHg}$ dan terendah $90 \mathrm{mmHg}$.

Tabel 5 .

Diskripsi frekuensi dan presentase tekanan darah sistole dan diastolic sebelum dilakukan terapi yoga pada kelompok intervensi dan kelompok kontrol

\begin{tabular}{lcccc}
\hline \multicolumn{1}{c}{$\begin{array}{c}\text { Variabel } \\
\text { Tekanan darah }\end{array}$} & \multicolumn{2}{c}{$\begin{array}{c}\text { Intervensi } \\
(\mathrm{n}=30)\end{array}$} & \multicolumn{2}{c}{$\begin{array}{c}\text { Kontrol } \\
(\mathrm{n}=30)\end{array}$} \\
\hline Sistole & $\mathrm{f}$ & $\%$ & $\mathrm{f}$ & $\%$ \\
Pre Hipertensi (120-139) & 0 & 0 & 0 & 0 \\
Hipertensi grade 1 (140-159) & 30 & 100,0 & 30 & 100,0 \\
\hline Diastolic & 0 & 0 & 0 & 0 \\
Pre Hipertensi (80-89) & 30 & 100,0 & 30 & 100,0 \\
Hipertensi grade 1 (90-94) & & & & \\
\hline
\end{tabular}

Hasil penelitian menunjukkan frekuensi dan presentase tekanan darah sistole dan Hipertensi grade 1 baik pada kelompok diastole sebelum dilakukan yoga dari 30 $(100,0 \%)$ responden mengalami intervensi dan kontrol.

Tabel 6.

Distribusi rata-rata tekanan darah sistole dan diastole setelah dilakukan terapi yoga pada kelompok intervensi dan kelompok kontrol

\begin{tabular}{|c|c|c|c|c|}
\hline Variabel & Mean & SD & Min & Maxl \\
\hline \multicolumn{5}{|c|}{ Tekanan darah sistole } \\
\hline Intervensi & 139,20 & 6,718 & 128 & 150 \\
\hline Kontrol & 145,87 & 5,582 & 138 & 154 \\
\hline \multicolumn{5}{|c|}{ Tekanan darah diastole } \\
\hline Intervensi & 86,67 & 2,591 & 82 & 92 \\
\hline Kontrol & 91,60 & 2,594 & 88 & 96 \\
\hline
\end{tabular}


standar deviasi 6,718. Tekanan sistole tertinggi $150 \mathrm{mmHg}$ dan terendah 128 mmHg. Kelompok kontrol sebesar $145,87 \mathrm{mmHg}$ (hipertensi grade 1) dengan standar deviasi 5,582. Tekanan darah sistole tertinggi $154 \mathrm{mmHg}$ dan terendah $138 \mathrm{mmHg}$.

Rata-rata tekanan darah diastole setelah perlakuan pada kelompok intervensi adalah 86,67 $\mathrm{mmHg}$ (pre hipertensi) dengan standar deviasi 2,591. Tekanan diastole tertinggi $92 \mathrm{mmHg}$ dan terendah $82 \mathrm{mmHg}$. Kelompok kontrol sebesar 91,60 $\mathrm{mmHg}$ (hipetensi grade 1) dengan standar deviasi 2,594. Tekanan darah diastole tertinggi $96 \mathrm{mmHg}$ dan terendah $88 \mathrm{mmHg}$.

Tabel 7.

Tekanan darah sistole dan diastolic setelah dilakukan terapi yoga pada kelompok intervensi dan kelompok kontrol

\begin{tabular}{ccccc}
\hline $\begin{array}{c}\text { Variabel } \\
\text { Tekanan darah }\end{array}$ & \multicolumn{2}{c}{$\begin{array}{c}\text { Intervensi } \\
(\mathrm{n}=30)\end{array}$} & \multicolumn{2}{c}{$\begin{array}{c}\text { Kontrol } \\
(\mathrm{n}=30)\end{array}$} \\
\hline Sistole & $\mathrm{f}$ & $\%$ & $\mathrm{f}$ & $\%$ \\
\hline Pre Hipertensi (120-139) & 13 & 43,3 & 6 & 20,0 \\
Hipertensi grade 1 (140-159) & 17 & 56,7 & 24 & 80,0 \\
Diastole & & & & 23,3 \\
Pre Hipertensi (80- 89) & 25 & 83,3 & 7 & 76,7 \\
Hipertensi grade 1 (90-94) & 5 & 16,7 & 23 &
\end{tabular}

Hasil penelitian ini menunjukkan diskripsi frekuensi dan presentase tekanan darah sistole setelah dilakukan terapi yoga pada kelompok intervensi sebagian besar Hipertensi grade 1 sebanyak 17 responden $(56,7 \%)$, Pre hipertensi sebanyak 13 responden (43,3\%). Kelompok kontrol sebagian besar hipertensi grade 1 sebanyak 24 responden $(80,0 \%)$, pre hipertensi sebanyak 6 responden $(20,0 \%)$.
Diskripsi frekuensi dan presentase tekanan darah diastole setelah dilakukan terapi yoga pada kelompok intervensi sebagian besar pre hipertensi sebanyak 25 responden $(83,3 \%)$, Hipertensi grade 1 sebanyak 5 responden (16,7\%). Kelompok kontrol sebagian besar hipertensi grade 1 sebanyak 23 responden $(76,7 \%)$, Pre hipertensi sebanyak 7 responden $(23,3 \%)$.

Tabel 8.

Hasil Analisa tekanan darah sebelum dan sesudah perlakuan pada kelompok intervensi dan kelompok kontrol

\begin{tabular}{|c|c|c|c|c|c|}
\hline Variabel & Kelompok & & Mean & SD & $P$ Value \\
\hline \multirow{4}{*}{$\begin{array}{l}\text { Tekanan } \\
\text { systole }\end{array}$} & Intervensi & Pre & 147,73 & 5,452 & 0,000 \\
\hline & & Post & 139,20 & 6,718 & \\
\hline & Kontrol & Pre & 148,87 & 5,673 & 0,000 \\
\hline & & Post & 145,87 & 5,582 & \\
\hline \multirow{4}{*}{$\begin{array}{l}\text { Tekanan darah } \\
\text { diastole }\end{array}$} & Intervensi & Pre & 94,27 & 2,504 & 0,000 \\
\hline & & Post & 86,67 & 2,591 & \\
\hline & Kontrol & Pre & 94,20 & 2,369 & 0,000 \\
\hline & & Post & 91,60 & 2,594 & \\
\hline
\end{tabular}

Tabel 8 menunjukan perbandingan mean tekanan darah sistol pada kelompok intervensi dan kelompok kontrol dengan $P=0,000, \quad p=0,000$. Ada pengaruh penurunan tekanan darah sistole pada kelompok intervensi dan kelompok kontrol, Meskipun ada pengaruh antara kedua kelompok dengan $p=0,000$ tetapi pada kelompok intervensi secara signifikan mampu menurunkan rata-rata tekanan darah sistole sebesar $8,64 \mathrm{mmHg}$ setelah diberikan terapi yoga. 
Perbandingan mean pada tekanan darah diastole pada kelompok intervensi dan kelompok kontrol juga memiliki $p=$ $0,000, p=0,000$. Artinya ada pengaruh penurunan tekanan darah diastole pada kelompok intervensi dan kelompok kontrol
, Meskipun ada pengaruh antara kedua kelompok dengan $p=0,000$ tetapi pada kelompok intervensi secara signifikan mampu menurunkan rata-rata tekanan darah diastole sebesar 7,6 $\mathrm{mmHg}$ setelah diberikan terapi yoga.

Tabel 9.

Hasil Analisis tekanan darah setelah perlakuan pada kelompok intervensi dan kelompok

\begin{tabular}{ccccc}
\multicolumn{4}{c}{ kontrol $(\mathrm{n}=30)$} & \\
\hline Variabel & Kelompok & Median & $\begin{array}{c}\text { Min } \\
\text { Max }\end{array}$ & $P$ value \\
\hline Tekanan darah sistole & $\begin{array}{c}\text { Intervensi } \\
\text { Kontrol }\end{array}$ & 144,00 & $128-154$ & 0,001 \\
\hline Tekanan darah diastole & $\begin{array}{c}\text { Intervensi } \\
\text { Kontrol }\end{array}$ & 88,00 & $82-96$ & 0,000 \\
\hline
\end{tabular}

Rata rata perbedaan tekanan darah sistole pada pasien hipertensi dengan menggunakan uji Mann Whitney test didapatkan nilai $p$ Value $0,000 \quad(<0.05)$ maka hipotesis nol (H0) ditolak. Sehingga dapat disimpulkan bahwa ada pengaruh terapi yoga terhadap penurunan tekanan darah sistole pada penderita Hipertensi.

Rata rata perbedaan tekanan darah diastole pada pasien hipertensi juga menggunakan uji Mann Whitney test didapatkan nilai $p$ Value $0,000 \quad(<0.05)$ maka hipotesis nol (H0) ditolak. Sehingga dapat disimpulkan bahwa ada pengaruh terapi yoga terhadap penurunan tekanan darah diastole pada penderita Hipertensi.

\section{Pembahasan \\ Karakteristik Responden}

Hasil penelitian menunjukan karakteristik responden berdasarkan umur responden pada kelompok intervensi adalah mayoritas berusia 41-50 tahun sebanyak 14 responden $(46,7 \%), 51-60$ tahun sebanyak 11 responden $(36,7 \%)$ dan 30-40 tahun sebanyak 5 responden $(16,7 \%)$. Kelompok kontrol 41-50 tahun sebanyak 15 responden (50,0\%), 51-60 tahun sebnayak 14 responden $(46,7 \%)$ dan 30-40 tahun sebanyak 1 responden $(3,3 \%)$. Responden pada penelitian ini semuanya berjenis kelamin perempuan karena perempuan lebih antusias untuk mengikuti yoga.
Berdasarkan penelitian yang dilakukan Previyanti (2013) mendapatkan jumlah responden yang mengalami hipertensi terbanyak adalah penduduk dengan usia $40-60$ tahun $(51,0 \%)$, berjenis kelamin perempuan $(51,0 \%)$. Smeltzer \& Bare (2007) mengemukakan perubahan struktural dan fungsional pada sistem pembuluh perifer bertanggung jawab pada perubahan tekanan darah yang terjadi seiring bertambahnya umur seseorang. Perubahan tersebut meliputi aterosklerosis, hilangnya elastisitas jaringan ikat, dan penurunan dalam relaksasiotot polos pembuluh darah, yang pada gilirannya menurunkan kemampuan distensi dan daya regang pembuluh darah. Konsekuensinya aorta dan arteri besar berkurang kemampuannya dalam mengakomodasi volume darah yang dipompa oleh jantung (volume sekuncup), mengakibatkan penurunan curah jantung, danpeningkatan tahanan perifer sehingga insidensi hipertensi meningkat seiring pertambahan usia.

Berdasarkan analisis data menunjukan bahwa karakteristik tingkat pendidikan responden pada kelompok intervensi dan kontrol mayoritas memiliki frekuensi yang sama yaitu paling banyak adalah tingkat pendidikan SMA sebanyak 19 responden $(63,3 \%)$ dan paling sedikit perguruan tinggi sebanyak 2 responden $(6,7 \%)$. Berdasarkan penelitian yang dilakukan oleh Albert (2015) menyatakan 
bahwa orang-orang dengan tingkat Pendidikan menengah atas lebih banyak yang mengalami Hipertensi di bandingkan dengan mereka yang berpendidikan rendah atau bahkan tidak pernah bersekelah sama sekali.

Hasil penelitian menunjukan karakteristik responden berdasarkan pekerjaan pada kelompok intervensi yaitu sebagian besar tidak bekerja sebanyak 20 responden $(66,7 \%)$, karyawan swasta 5 responden $(16,7 \%)$, wiraswasta 3 responden (10\%) dan Pegawai negri sipil 2 responden $(6,7 \%)$. Kelompok control sebagian besar tidak bekerja sebanyak 18 responden $(60,0 \%)$, wiraswasta 6 responden $(20,0 \%)$, karyawan swasta 5 responden $(16,7 \%)$ dan pegawai negri sipil 1 responden (3,3\%). Berdasarkan pekerjaan penelitian ini didapatkan responden yang terbanyak adalah yang tidak bekerja karena merekan lebih sering menghabiskan waktunya di rumah dan meluangkan waktunya untuk mengikuti yoga. Hal ini selaras dengan penelitian Basofi (2016) yang mendapatkan pasien terbanyak ialah yang tidak bekerja dengan jumlah 30 orang $(61,22 \%)$. Al-Saffar dan Saeed (2009) menyatakan terdapat hubungan antara pekerjaan dan kecemasan. Hal ini sesuai dengan hasil penelitian ini semua responden mengalami kecemasan pada semua jenis pekerjaan.

\section{Yoga}

Yoga adalah keterampilan yang spiritual yang mengolah fisik dan jiwa karena gerakan yoga menyeimbangkan energi dan memberi kenyamanan tubuh bahkan juga meremajakan sel-sel kulit mati (Setiawan, 2008). Yoga mengkombinasikan antara teknik bernapas, relaksasi dan meditasi serta latihan peregangan (Jain, 2011).

Yoga merupakan alat modifikasi gaya hidup terbaik untuk pencegahan penyakit kardiovaskular karena mengandung unsur meditasi. Yoga digunakan sebagai terapi tambahan yang efektif untuk pencegahan hipertensi karena dapat merubah gaya hidup menjadi positif (shah, 2016). Yoga merupakan kombinasi dari latihan fisik terstruktur, teknik pernapasan, dan meditasi, dan terbukti secara positif mempengaruhi fungsi otonom jantung. Telah terbukti mengurangi gejala depresi dan kecemasan dan menghasilkan peningkatan kualitas hidup (Field, 2016).

\section{Tingkat Hipertensi sebelum diberikan yoga}

Hasil penelitian ini menunjukan ratarata tekanan darah sistole $147,73 \mathrm{mmHg}$ pada kelompok intervensi dan 148,87 mmHg pada kelompok kontrol, sehingga dalam penilaian tingkat derajat hipertensi pada kedua kelomok adalah Hipertensi grade 1. Rata-rata tekanan darah diastole 94,27 $\mathrm{mmHg}$ pada kelompok intervensi dan $94,20 \mathrm{mmHg}$ pada kelompok kontrol, sehingga dalam penilaian tingkat derajat hipertensi pada kedua kelompok ada Hipertensi grade 1.

Hipertensi merupaka keadaan dimana tekanan darah sistole $\geq 140 \mathrm{mmHg}$ dan atau tekanan darah diastole $\geq 90$. Hipertensi dapat menyebabkan stroke, retinopathy kebutaan, penyakit jantung koroner hingga gagal jantung, gagal ginjal kronis hingga kegagalan ginjal terminal (Bild et al., 2014). Penyebab Hipertensi tidak dapat ditentukan secara pasti tetapi ada gangguan fungsional yang sangat terkait dengan gaya hidup seseorang. Faktor-faktor risiko yang mempengaruhi terjadinya hipertensi adalah kelebihan berat badan, diabetes, asupan garam yang berlebihan, diet tinggi lemak, merokok, konsumsi alkohol yang berlebihan, Selain itu pengaruh faktor risiko emosional seperti kecemasan, depresi dan pengaruh negatife yang telah ditunjukan (Marthy, 2011).

Gaya hidup sangat penting bagi semua orang karena gaya hidup berhubungan dengan kesehatan seseorang terutama masalah Hipertensi. Kenaikan 
tekanan darah sering terjadi tanpa gejala yang jelas sehingga orang tidak akan sadar bahwa dirinya mengalami Hipertensi (Wang et al., 2015).

\section{Tingkat Hipertensi setelah diberikan yoga}

Hasil penelitian ini menunjukan ratarata tekanan darah sistole setelah diberikan yoga pada kelompok intervensi adalah $139,20 \mathrm{mmHg}$ (Pre hipertensi) dan 145,87 $\mathrm{mmHg}$ (Hipertensi grade 1) pada kelompok kontrol. Rata-rata tekanan darah diastole pada kelompok intervensi adalah 86,67 mmHg (pre hipertensi) dan 91,60 $\mathrm{mmHg}$ (hipertensi grade 1) pada kelompok kontrol. Hasil tingkat tekanan darah pada kedua kelompok mengalami perbedaan, pada kelompok intervensi mengalami tingkat derajat pre hipertensi pada tekanan sistole dan diastole. Tingkat derajat hipertensi pada kelompok kontrol masih pada tingkat derajat Hipertensi grade 1 pada tekanan darah sistole dan diastole. Penelitian Tolbanos (2014) diketahui peran yoga dalam pengobatan gangguan kardiovaskular menunjukkan efek yang menguntungkan karena terdapat penurunan tekanan darah sistole dan diastole dan denyut jantung.

\section{Perbedaan Pengaruh Yoga Terhadap Penurunan Tekanan pada Hipertensi}

Hasil penelitian menunjukan perbedaan mean tekanan darah sistole pada kelompok intervensi dan kelompok kontrol dengan $p=0,000, p=0,000$. Artinya ada pengaruh penurunan tekanan darah sistole pada kelompok intervensi dan kelompok kontrol, Meskipun ada pengaruh antara kedua kelompok dengan $p=0,000$ tetapi pada kelompok intervensi secara signifikan mampu menurunkan rata-rata tekanan darah sistole sebesar 8,64 $\mathrm{mmHg}$ setelah diberikan yoga di bandingkan pada kelompok yang tidak diberikan yoga.

Perbedaan mean pada tekanan darah diastole pada kelompok intervensi dan kelompok kontrol juga memiliki $p=0,000$, $p=0,000$. Artinya ada pengaruh penurunan tekanan darah diastole pada kelompok intervensi dan kelompok kontrol, Meskipun ada pengaruh antara kedua kelompok dengan $p=0,000$ tetapi pada kelompok intervensi secara signifikan mampu menurunkan rata-rata tekanan darah diastole sebesar $7,6 \mathrm{mmHg}$ setelah diberikan yoga dibandingkan kelompok yang tidak diberikan yoga.

Berdasarkan penelitian yang dilakukan Murthy (2011) berpendapat bahwa yoga mampu menurunkan tekanan darah karena yoga mengandung unsur relaksasi yang mampu menurunkan tekanan sistole sebesar $4.7 \mathrm{mmHg}$ dan tekanan diastole sebesar $3,3 \mathrm{mmHg}$. Penelitian ini tekanan darah rata-rata turun dari 139,6 menjadi 129,6 pada kasus tekanan darah sistole sementara turun dari 91,2 menjadi 86,1 untuk tekanan darah diastole. Sehingga dapat disimpulkan bahwa yoga efektif dalam menurunkan tekanan darah pada pasien hipertensi ringan sampai sedang bahkan tanpa mengkonsumsi obat .

Yoga juga bermanfaat bagi pasien yang baru terdiagnosa hipertensi sehingga dapat menunda menuju tingkatan hipertensi yang lebih tingga serta menghindari komplikasi penyakit kardiovaskuler. Yoga juga bermanfaat dalam pengobatan gangguan kardiovaskuler seperti menurunkan tekanan darah sistole dan diastole dan mengurangi denyut jantung. yoga juga bermanfaat untuk membuat fikiran seseorang menjadi lebih positif serta dapat menurunakan kecemasan dan stress seseorang. Hal tersebut terjadi karena yoga mengandung unsur relaksasi (Fuchs, 2012).

Penelitian ini juga sesuai dengan penelitian yang dilakukan Lakkireddy (2013) dengan hasil hasil terjadi penurunan signifikan pada denyut jantung, tekanan darah sistoloe dan diastole sebelum dan sesudah yoga dengan nilai $\mathrm{p} 0,001$. Artinya ada pengaruh yang signifikan terhadapa penurunan tekanan darah sistole dan diastole. Adanya penurunan tekanan darah sistole dan diastole kelompok eksperimen dapat disebabkan karena sistem limbik akan 
teraktivasi dan menjadikan individu menjadi rileks yang dapat menurunkan tekanan darah. Yoga merupakan penggabungan antara latihan peregangan dan latihan pernafsan, latihan peregangan akan menjadika otot lebih lentur hal ini membuat peredaran darah lebih lancar dan hasilnya tekanan darah yang menurun atau normal.

Latihan pernapasan pada yoga dengan cara mengatur napas menjadi lebih pelan dan dalam berfungsi menenangkan pikiran dan tubuh, pada saat latihan pernapsa dilakukan otot-otot tubuh akan meregang, sehingga tubuh dan pikiran menjadi rileks, nyaman dan tenang yang membuat tekanan darah menurun (Oktavia, 2012) Penurunan pada tekanan darah disebabkan karena relaksasi pada yoga prinsipnya adalah memposisikan tubuh dalam kondisi tenang, sehingga akan mengalami relaksasi dan pada akhirnya akan mengalami kondisi keseimbangan, dengan demikian relaksasi pada yoga berintikan pada pernafasan yang akan meningkatkan sirkulasi oksegen ke otototot, sehingga otot-otot akan mengendur, tekanan darah akan menurun (Triyanto, 2014).

\section{Simpulan dan Saran}

Hasil penelitian didapatkan secara signifikan yoga mampu menurunkan ratarata tekanan darah sistole pada kelompok yang melakukan yoga sebesar 8,64 $\mathrm{mmHg}$ dibandingkan kelompok yang tidak melakukan yoga. Dengan nilai $p$ value $0,000(p<0,05)$. Artinya ada pengaruh penurunan tekanan darah sistole setelah diberikan terapi yoga.

Yoga juga secara signifikan mampu menurunkan rata-rata tekanan darah diastole pada kelompok yang melakukan yoga sebesar 7,6 mmHg dibandingkan kelompok yang tidak melakukan yoga. Dengan $p$ value $0,000(p<0,05)$. Artinya ada pengaruh penurunan tekanan darah diastole setelah diberikan terapi yoga. Sehingga dapat disimpulkan terapi yoga bermanfaat untuk menurunkan tekanan darah baik sistole maupun diastole.

Penelitian ini membuktikan bahwa yoga mampu menurunkan kecemasan dan menurunkan tekanan darah pasien hipertensi, sehingga yoga sangat dianjurkan untuk diterapkan kepada pasien hipertensi dalam menurunkan kecemasan dan tekanan darah. Yoga dapat digunakan sebagai pengobatan alternative bagi pasien hipertensi, sehingga dapat diaplikasikan kepada masyarakat dengan membiasakan olahraga secara rutin. Diharapkan peneliti selanjutnya dapat menggunakan penelitian ini sebagai referensi dalam melakukan penelitian mengenai yoga dalam menurunkan kecemasan dan tekanan darah pada pasien hipertensi. Peneliti selanjutnya disarankan untuk dapat menambah jumlah responden dan memberikan yoga lebih dari 6 kali sehingga dapat menurunkan kecemasan dan tekanan darah lebih banyak dari penelitian ini.

\section{Daftar Pustaka}

Agrina, S.S., Hairitama R. (2011). Kepatuhan Lansia Penderita Hipertensi Dalam Pemenuhan Diet Hipertensi [Jurnal]. Fakultas keperawatan: Pekanbaru (Riau).

Albert, U. K., \& Effiong, J. H. (2015). Risk factors and anthropometric variables of young people with essential hypertension in Uyo, Akwa Ibom State. British Journal of Medicine \& Medical Research, 10(8).

Bo Hu, Xiaoyu Liu, Sufeng Yin, Hongmin Fan, Fumin Feng, Juxiang Yuan (2015). Effects of psychological stress on Hypertension in MiddleAged Chiness : A Cross Sectional Study. Plos One 10(6):pp.113.doi:10.1371/journal.pone.012916 3

Jain, Ritu (2011). Pengobatan alternatif untuk mengatasi tekanan darah. Jakarta: Gramedia Pustaka Utama. 
Kelana, K (2011). Metodologi Penelitian Keperawatan. Jakarta: Cv Trans Info Media.

Kowalski, E. Robert (2010). Terapi Hipertensi. Bandung :Qanita

Murthy, S. N., Rao, N. S. N., Nandkumar, B., \& Kadam, A. (2011). Role of naturopathy and yoga treatment in the management of hypertension. Complementary Therapies in Clinical Practice, 17(1), 9-12. https://doi.org/10.1016/j.ctcp.2010.0 $\underline{8.005}$

Parshad O, Richards A, Asnani M.(2011). Impact of yoga on haemodynamic function in healthy medical students. West Indian Med $J$ [Internet]. 60(2):148-52.Available from:http://www.ncbi.nlm.nih.gov/p ubmed/21942118

Prayitno, B. (2014). Meditasi. Yogyakarta: Flashbooks.

Previyanti, LP, Sudhana I wayan. (2013). Gambaran prevalensi dan faktor resiko hipertensi pada penduduk usia produktif di desa rendang, kecamatan rendang, kabupaten karangasem [Jurnal]. Fakultas kedokteran Universitas Udayana : Bali.

Field, Tiffany. (2016). Yoga research review. Complementary Therapies in Clinical Practice $145 \mathrm{e} 161$

T. Fuchs, in: J. Fingerhut, S. Marienberg (Eds.).(2012).The Feeling of Being Alive. Organic Foundations of Self Awareness, de Gruyter Verlag, Berlin.149e166.

Wang, H., Wong, M., Mok, R., Kwan, M., Chan, W. M., Fan, C. Griffiths, S. (2015). Factors associated with grade 1 hypertension: implications for hypertension care based on the dietary approaches to stop hypertension (DASH) in primary care settings. BMC Family Practice, 16(1), 26. doi: 10.1186/s128750150239-4

WHO. 2010. A global brief on hypertension. Di dapat dari http://www.searo.WHO.int/linkfiles/ non_communicable_diseases_hypert ension fs.Pdf

Wirawanda, Y. (2013). Kedahsyatan terapi yoga. Jakarta timur : Padi. 